\title{
KAJIAN LOKUSI, ILOKUSI, DAN PERLOKUSI DALAM WACANA KELAS AKSELERASI SMPN I KOTA BENGKULU
}

\author{
Novia Sari
}

\begin{abstract}
Abstrak
This thesis due to describe the speech act of locution, llocution, and perlocution text in opening, explaning, and closing the lesson in VIII th acceleration class in SMPN I Kota Bengkulu. The method that use in this thesis is qualitative descriptive. In collecting the data the writer used these steps: a) transcription, b) coding, c) identification and classification, d) analyzing the data, e) conclution. From the analized and descation can be conclude that teacher and students when did the classroom interaction in opening, explaining, and closing, used locution act such as question, informing, instruction stating, greeting, perfoming, agreement, giving turn, asking, giving opinion, suggestion, remining, explaining, reading, exclamatory, instructing, informing, agreement, and greeting. Ilocution act such as question, informing, instruction, stating, greeting, performing, agreement, giving turn, asking, and saying thanks. Speech act that usually used were questioning instructing, informing, agreement and greeting. llocution that used by the teacher and student. In opening the lesson, explaining and closing the lesson, direct act, accretive, expressive and comissive. The act that dominant are direct act. The direct act that common found in this term were questioning, imperative that used question words. For exampale "Kalau begitu apa sih Sirkum Pasifik dan Sirkum Mediterania?". Imperactive direct speech act signed by imperative verb. Than add by verb kan and verb lah. Example of direct imperative "“Silakan...". The expression that used were greeting and saying thank by using linguistics character, "Terima kasih, $B u^{\prime \prime}$. Acertive act that found were statement and explanation. In a while tie comissive promising act. In linguistics act promising something such as "Buku paket akan diantar nanti..." Perlocution act in opening that lesson, explaining the lesson, as act that responanble and undestanable, responable and un undestenable also speech act that undestanable by the teacher or the student.
\end{abstract}

Key word: speech act, classroom talk, locution, ilocution, perlocution

\section{Pendahuluan}

Interaksi dalam peristiwa bahasa, khususnya pada pembelajaran merupakan peristiwa komunikasi antarkompenen yang membangun dalam kegiatan pembelajaran. Dalam interaksi kelas, terjadi aktivitas pertukaran informasi atau ide antar guru dan siswa, atau sebaliknya, dan antara siswa dengan siswa lainnya. Dalam proses informasi itu, antara guru dengan siswa, atau siswa dengan siswa (pembicaralawan bicara) tidak hanya berwujud ekspresi verbal, tetapi juga melibatkan ekspresi nonverbal dalam mengungkapkan pesan (idenya).

Penggunaan bahasa dalam pembelajaran di kelas merupakan realitas komunikasi yang berlangsung dalam interaksi kelas. Dalam interaksi kelas, guru selalu menggunakan bahasa untuk memperlancar proses komunikasi guna mencapai tujuan pembelajaran. Guru yang profesional dan berpengalaman akan mampu mengembangkan interaksi yang bervariasi dan menyenangkan sebab penciptaan interaksi kelas merupakan bagian dari proses pengelolaan kelas dalam suatu kegiatan belajar mengajar. 
Sementara idealnya, komunikasi dalam proses pembelajaran adalah pembicaraan dua arah antara guru dan siswa. Keinginan kedua belah pihak dapat tersampaikan guna mencapai tujuan pembelajaran. Interaksi edukatif pada dasarnya adalah komunikasi timbal balik antar peserta didik dengan pendidik dengan sistem pengajaran bertumpu kepada anak yang terarah kepada tujuan pembelajaran yang ditempuh melalui proses berkomunikasi intensif ke arah mana bimbingan ditujukan (tujuan pembelajaran). Komunikasi yang jelas merupakan salah satu syarat pembelajaran dapat berlangsung efektif. Berdasar fenomena tersebut, ujaran guru merupakan wacana kelas yang membentuk komunikasi khas selama pembelajaran berlangsung. Penelitian ini hanya terfokus pada ujaran guru dalam interaksi kelas (proses pembelajaran). Dalam wacana kelas, tuturan guru dan siswa dalam interaksi belajar mengajar, meliputi wacana membuka pelajaran, menerangkan pelajaran (inti), dan menutup pelajaran.

Penelitian tentang kajian lokusi, ilokusi, dan perlokusi guru dan siswa dalam proses pembelajaran perlu dilaksanakan untuk menganalisis dan mendeskripsikan tentang makna ujaran guru dan siswa, pemahaman siswa maupun guru terhadap ujaran yang ada, serta efek yang ditimbulkan dari suatu ujaran terhadap siswa maupun guru dalam wacana kelas, ketika guru membuka, menerangkan, dan menutup pelajaran. Dengan demikian dirumuskan masalah; (a) bagaimana lokusi, ilokusi, dan perlokusi dalam wacana kelas akselerasi SMPN I Kota Bengkulu ketika guru membuka pelajaran? (b) bagaimana lokusi, ilokusi, dan perlokusi dalam wacana kelas akselerasi SMPN I Kota Bengkulu ketika guru menerangkan pelajaran? (c) bagaimana lokusi, ilokusi, dan perlokusi dalam wacana kelas akselerasi SMPN I Kota Bengkulu ketika guru menutup pelajaran?

Berdasarkan rumusan masalah tersebut, dirumuskan tujuan penelitian sebagai berikut; tujuan umum penelitian ini untuk mendeskripsikan tindak tutur guru dan siswa dalam wacana kelas membuka pelajaran, menerangkan (inti pelajaran), dan menutup pelajaran di Kelas VIII Akselerasi SMPN I Kota Bengkulu. Sedangkan secara khusus penelitian ini bertujuan: (a) mengetahui lokusi, ilokusi, dan perlokusi dalam wacana kelas akselerasi SMPN I Kota Bengkulu ketika guru membuka pelajaran? (b) mengetahui lokusi, ilokusi, dan perlokusi dalam wacana kelas akselerasi SMPN I Kota Bengkulu ketika guru menerangkan pelajaran (inti)? Dan (c) mengetahui lokusi, ilokusi, dan perlokusi dalam wacana kelas akselerasi SMPN I Kota Bengkulu ketika guru menutup pelajaran?

Dengan demikian dirumuskan manfaat penelitian yang secara praktis adalah memberikan informasi mengenai interaksi kelas, yakni tentang tuturan guru dan siswa dalam mengatakan sesuatu (lokusi), pemahaman guru dan siswa terhadap tuturan (ilokusi), serta efek dari tuturan guru maupun siswa (perlokusi) dalam proses belajar mengajar, baik ketika guru membuka pelajaran, menerangkan pelajaran, maupun saat menutup pelajaran. dan mengembangkan interaksi kelas, terutama dalam melakukan pengelolaan kelas. Guru dapat meningkatkan proses dan Temuan pembelajaran, guna tercapainya tujuan pembelajaran yang 
diharapkan melalui interaksi dan komunikasi yang dialogis (dua arah) dengan siswa.

Metode yang digunakan dalam penelitian ini adalah deskriptif kualitatif yakni metode yang mencoba menggambarkan dan menganalisis data, mulai dari tahap pengumpulan, penyusunan data dibarengi dengan analisis dan interpretasi terhadap datadata tersebut. Penelitian ini merupakan penelitian deskriptif kualitatif dengan pendekatan content analisis dengan tidak mengabaikan konteks dalam dialog. Analisis isi berhubungan dengan komunikasi atau isi komunikasi. Secara deskriptif penelitian ini dilakukan semata-mata berdasarkan pada fakta yang ada atau fenomena yang memang secara emperis dilakukan oleh penuturnya. Secara kualitatif dengan pendekatan content analysis bertujuan mengungkapkan isi dan pesanpesan/maksud yang terkandung pada setiap ujaran berdasarkan hubungan kerja samanya pada setiap ujaran yang dikemukakan oleh guru maupun siswa. Lokasi penelitian di kelas VIII akselerasi SMPN I Kota Bengkulu yang beralamat di Jalan Sudirman Kota Bengkulu. Sementara itu, subyek penelitian ini adalah guru dan siswa kelas VII Akselerasi SMPN I Kota Bengkulu. Guru yang menjadi subyek dalam penelitian ini, diseleksi berdasarkan kriteria berikut: (a) humanistik, yakni guru yang memperlakukan siswa dengan penuh respect, menaruh perhatian pada siswa di setiap percakapan atau diskusi, guru yang menanyai dan mengungkap keadaan siswa dan sebaliknya siswa mengajukan berbagai persoalanpersoalan dan hambatan yang sedang dihadapi, (b) guru yang berkomunikasi dengan jelas dalam menyampaikan informasi kepada siswa, dan (c) guru yang mempunyai kemampuan mendengar dengan seksama.

Berdasarkan kriteria tersebut, guru yang menjadi subjek dalam penelitian berjumlah empat orang, yakni Refendi Tampubolon, M.Pd. mengajar mata pelajaran TIK dan Juhariah, S.Pd. untuk bidang studi IPS. Selanjutnya, siswa yang menjadi subyek adalah siswa kelas VIII akselerasi yang berjumlah 20 orang. Seluruh siswa dijadikan subyek penelitian. Berdasarkan Temuan penelitian Balitbang Depdikbud (1986) menyebutkan bahwa siswa kelas akselerasi atau disebut juga siswa cerdas istimewa memiliki karakteristik: sangat peka dan waspada, mempunyai pengetahuan umum yang luas, lancar berbahasa, sangat logis, cepat berespon secara verbal dengan tepat, mampu berkonsentrasi, mempunyai daya ingat yang baik, lebih menyukai kegiatan verbal daripada kegiatan tertulis, bisa belajar sendiri dalam bidang-bidang yang diminati, mempunyai tujuan yang jelas dalam setiap kegiatan, cermat atau teliti dalam mengamati, memiliki perbendaharaan kata yang luas, mempunyai daya imajinasi yang kuat, dapat memberikan banyak gagasan, dan dapat berkomunikasi secara baik dengan orang dewasa, bahkan lebih baik daripada jika berkomunikasi dengan anak sebayanya.

Data dalam penelitian ini adalah tuturan guru dan siswa dalam wacana kelas akselerasi SMPN I Kota Bengkulu yang dianalisis dari tindak lokusi, ilokusi, dan perlokusi. Data tersebut ditranskripsikan dari Temuan rekaman melalui alat perekam. Transkip tulisan yang diambil dari data rekaman yang 
lengkap dengan konteks.Teknik pengumpulan data dalam penelitian ini melalui, (1) rekaman, dan (2) observasi atau pengamatan langsung di lapangan. Teknik pengumpulan data dalam penelitian ini menggunakan teknik observasi langsung sebagai metode utama, dan dilengkapi dengan catatan lapangan, serta wawancara.

Analisis data adalah suatu kegiatan dalam penelitian yang bertujuan untuk mengolah data-data yang diperoleh, agar bisa dibaca dan mudah dipahami (Dhohiri dkk. 2000:129). Analisis data merupakan bagian yang sangat penting dalam metode ilmiah, karena dengan analisis data dapat diberi arti, makna yang berguna dalam memecahkan masalah penelitian itu sendiri. Langkahlangkah analisis data dalam penelitian ini, (1) mentranskripsikan data Temuan rekaman, (2) pengkodean data, dan mengklasifikasikan data.

\section{Temuan Penelitian Dan Pembahasan}

Berdasarkan rumusan masalah dan tujuan penelitian, berikut ini disajikan Temuan penelitian mengenai kajian lokusi, ilokusi, dan perlokusi dalam wacana kelas akselerasi SMPN I Kota Bengkulu. Pemaparan Temuan penelitian diurutkan berdasarkan rumusan masalah. Pemaparan yang dimaksudkan adalah: (1) lokusi, ilokusi, dan perlokusi dalam wacana kelas akselerasi SMPN I Kota Bengkulu ketika guru pembuka pelajaran, (2) lokusi, ilokusi, dan perlokusi dalam wacana kelas akselerasi SMPN I Kota Bengkulu ketika guru menerangkan pelajaran, (3) lokusi, ilokusi, dan perlokusi dalam wacana kelas akselerasi SMPN I Kota Bengkulu ketika guru menutup pelajaran.
Temuan dan pembahasan secara detail dapat dibaca pada tabel frekuensi temuan tuturan lokusi, ilokusi, dan perlokusi berikut.

\section{(a) Tuturan Lokusi}

Berdasarkan Temuan analisis data yang telah peneliti lakukan, ditemukan tuturan lokusi dalam interaksi kelas berbentuk kalimat yang bermaksud menyatakan sesuatu/ informasi, tanpa tendensi untuk melakukan sesuatu, apalagi untuk mempengaruhi lawan tuturnya.

\section{(b) Tuturan Ilokusi}

Berdasarkan penelitian yang penulis lakukan pada tuturan guru dan siswa dalam interaksi kelas membuka pelajaran mengandung tuturan ilokusi berbentuk tuturan yang selain bermaksud untuk menyatakan sesuatu, juga berfungsi melakukan sesuatu. Dalam tuturan lokusi, satu tuturan mengandung dua maksud.

\section{(c) Tuturan Perlokusi}

Berdasarkan Temuan analisis data yang telah peneliti lakukan, ditemukan tuturan perlokusi dalam interaksi kelas berbentuk tuturan yang merupakan Temuan atau efek yang ditimbulkan oleh tuturan (terhadap pendengar).

\section{Pembahasan}

Setelah dikaji dari tuturan guru dan siswa dalam wacana membuka pelajaran, menerangkan pelajaran, dan menutup pelajaran di kelas VIII akselerasi SMPN I Kota Bengkulu, diketahui bahwa guru dan siswa dalam interaksi kelas menggunakan tuturan lokusi, ilokusi, dan perlokusi. Tuturan lokusi, ilokusi, dan 
perlokusi ini terjadi karena penutur dan mitra tutur dalam berkomunikasi tidak hanya mengucapkan kalimat tuturan dengan maksud untuk mengatakan sesuatu saja, tetapi juga berfungsi melakukan sesuatu atau tindak tutur. Hal ini sesuai dengan pendapat Searle (dalam Ibrahim, 1995:143).

Berdasarkan Temuan penelitian yang penulis lakukan dalam wacana kelas membuka pelajaran, diketahui bahwa tuturan lokusi yang digunakan adalah tuturan yang dimaksudkan untuk menyampaikan sesuatu/ informasi yang disampaikan penutur/ penulis kepada lawan tutur/ pembaca, tanpa tendensi untuk melakukan sesuatu, apalagi untuk mempengaruhi lawan tuturnya. (Rahmadi, 2008:205). Tuturan lokusi yang ditemukan adalah tuturan yang selain untuk menyatakan sesuatu, juga berfungsi untuk melakukan sesuatu. Dalam tuturan lokusi, berarti satu tuturan mengandung dua maksud (Rahmadi (2008:207). Tuturan ilokusi yang dominan digunakan guru dan siswa dalam wacana membuka pelajaran adalah tuturan menginstruksikan, menginformasikan, dan mengucap salam. Hal tersebut disebabkan bahwa dalam memulai interaksi belajar mengajar, guru membangun komunikasi dengan mengondisikan kelas terlebih dahulu. Seperti instruksi kepada ketua kelas untuk menyiapkan kelas tanda dimulainya pemelajaran, menginformasikan mengenai materi yang akan dipelajari, serta memberikan ucapan yang lembut pada waktu pelajaran dimulai, seperti "Selamat pagi anak-anak". Hal ini dimaksudkan supaya siswa merasa siap dan bersemangat, sehingga pemelajaran akan berjalan secara kondusif.
Tuturan ilokusi yang dominan diTemuankan guru dan siswa dalam wacana kelas membuka pelajaran, sesuai kategori Searle dalam Rahardi (2003:72), yaitu berupa tuturan direktif dan asertif. Guru dan siswa lebih cenderung menggunakan tuturan direktif untuk memerintah, bertanya, dan memberitahu. Tuturan asertif disampaikan siswa dan guru untuk menyatakan sesuatu dan mengucapkan salam. Tuturan-tuturan tersebut lebih banyak diTemuankan, karena ketika membuka pelajaran, guru tidak hanya mengatakan atau menyatakan sesuatu saja, tetapi juga mendorong siswa untuk melakukan sesuatu sesuai dengan keinginan-keinginan guru. Seperti, mendorong dan membangkitkan siswa untuk berpartisipasi dalam kegiatan belajar mengajar, bertanya untuk merangsang respon siswa, mengaktifkan siswa, dan menyegarkan kembali pengetahuan siswa terhadap materi yang akan dibahas, serta memfokuskan perhatian siswa pada sesuatu yang dikehendaki guru.

Tuturan perlokusi yang digunakan guru dalam wacana kelas ini adalah tuturan yang memberikan efek direspon dan dipahami maknanya oleh siswa. Hal tersebut dikarenakan siswa memahami maksud dari tuturan guru dan merespon menunjukkan adanya perhatian siswa terhadap pelajaran. Berkaitan dengan rumusan kedua dalam penelitian ini, yaitu tuturan lokusi, ilokusi, dan perlokusi dalam wacana menerangkan pelajaran, penulis menemukan tuturan lokusi bertanya, membenarkan, dan menginstruksikan. Tuturan bertanya lebih dominan digunakan karena guru ingin mengukur pemahaman serta pengetahuan siswa seputar materi yang 
dibahas. Pertanyaan-pertanyaan yang diajukan guru lebih banyak bersifat mendasar dan terkesan bertele-tele atau mubazir untuk diujikan kepada siswa akselerasi.

Tuturan perlokusi yang diTemuankan dalam wacana menerangkan pelajaran yaitu tuturan yang merupakan Temuan atau efek yang ditimbulkan oleh tuturan terhadap pendengar. Tuturan perlokusi mengandung maksud yang diinginkan oleh penutur agar keinginannya tampak wujudnya dalam tindakan. (Junaiyah dan Zaenal, 2010:119). Perlokusi yang mendominasi adalah tuturan direspon dan dipahami. Sikap ini menunjukkan bahwa siswa mengerti, memperhatikan, menyimak, dan memahami pertanyaan, penjelasan, maupun keinginan-keinginan dibalik tuturan yang disampaikan guru.

Rumusan masalah ketiga dalam penelitian ini adalah tuturan lokusi, ilokusi, dan perlokusi dalam wacana kelas menutup pelajaran. Dalam interaksi kelas, tuturan lokusi yang digunakan guru dan siswa adalah tuturan menginstruksikan, menginformasikan, dan mengucapkan salam. Tuturantuturan tersebut sering diucapkan, karena dalam mengakhiri pelajaran, guru menginstruksikan ketua kelas untuk menyiapkan kelas tanda ditutupnya pelajaran, menginformasikan kepada siswa untuk mempelajari kembali di rumah materi yang baru saja dibahas dan menginformasikan tugas-tugas yang harus dikerjakan siswa, serta mengucapkan "selamat siang, sampai bertemu minggu depan", sebagai akhir dari rangkaian proses belajar mengajar. Tuturan ilokusi yang sering digunakan guru dalam wacana menutup pelajaran, yaitu tuturan direktif dan tuturan komisif. Tuturan ini lebih mendominasi karena dalam mengakhiri penjelasan, guru berkeinginan agar ketua kelas menyiapkan kelas sebagai tanda telah selesainya tatap muka pada jam pelajaran tersebut. Guru juga memberitahu siswa mengenai materi yang akan dipelajari pada pertemuan berikutnya, mendorong siswa untuk mempelajari kembali materi di rumah dengan maksud untuk mengukur seberapa jauh materi dapat diterima, dipahami, dan diketahui siswa.

Tuturan perlokusi yang terdapat dalam proses akhir interaksi belajar mengajar, yaitu tuturan direspon dan dipahami. Hal ini menimbulkan perilaku yaitu siswa menyambut dengan senang hati hal-hal yang dikemukakan guru, baik mengenai tugas untuk mempelajari kembali materi di rumah maupun telah berakhirnya jam pelajaran. Siswa memberikan betuk penghargaan berupa rasa hormat kepada guru karena telah membimbing mereka dengan mengucapkan salam dan terima kasih.

\section{Kesimpulan}

Berdasarkan Temuan penelitian dan pembahasan, dapat disimpulkan bahwa tuturan lokusi, ilokusi, dan perlokusi digunakan guru dan siswa dalam wacana interaksi kelas membuka pelajaran, menerangkan pelajaran, dan menutup pelajaran. Tindak tutur tersebut disampaikan guru dan siswa guna memperlancar komunikasi dan proses belajar mengajar.

Tuturan lokusi yang digunakan guru dan siswa dalam wacana membuka pelajaran, menerangkan pelajaran, dan menutup pelajaran. Tuturan tersebut berupa tuturan yang bermaksud mengatakan sesuatu dengan makna sebenarnya. Seperti tuturan 
bertanya, menginformasikan, menginstruksikan, menyatakan, mengucapkan salam, menjanjikan, membenarkan, memberi kesempatan, meminta, menyampaikan pendapat, meminta, menasihati, mengingatkan, menjelaskan, membacakan, memuji, dan mengucapkan terima kasih. Tuturan bertanya merupakan tuturan yang paling banyak ditemukan dari data yang dianalisis. Hal ini menunjukkan bahwa dalam interaksi kelas, mengarah pada proses ceramah dan tanya jawab.

Tuturan ilokusi yang diTemuankan guru dan siswa dalam interaksi kelas ketika membuka pelajaran, menerangkan pelajaran, dan menutup pelajaran, ditemukan berupa tuturan direktif, tuturan asertif, tuturan ekspresif, dan tuturan komisif. Wujud dari tuturan direktif yang digunakan, seperti memerintah, bertanya, memberitahu, membenarkan, mengakui, menasihati, mengemukakan pendapat, serta menyetujui. Tuturan asertif disampaikan untuk mengakui, menjelaskan, dan mengemukakan pendapat. Sedangkan tuturan asertif digunakan untuk mengucapkan salam dan mengucapkan terima kasih. Dari keempat jenis tuturan ilokusi yang ditemukan tersebut, tuturan lebih mendominasi digunakan dalam interaksi kelas.

Tuturan perlokusi yang digunakan guru dan siswa dalam wacana membuka pelajaran, menerangkan pelajaran, dan menutup pelajaran, berbentuk tuturan direspon dan dipahami, direspon dan tidak dipahami, serta tidak dipahami. Dalam tuturan direspon dan dipahami, baik guru maupun siswa sama-sama dapat menanggapi dengan memberikan respon yang tepat dan sesuai dengan makna tuturan. Tuturan ini memberikan efek berupa tindakan yang penuh perhatian, berpartisipasi, dan aktif dalam pemelajaran.

Tuturan direspon dan tidak dipahami digunakan karena siswa dan guru kurang jelas atau kurang mengerti dengan tuturan yang ada, sehingga merespon dengan bertanya. Sedangkan tuturan tidak dipahami, berarti antara penutur dengan mitra tutur tidak terjalin komunikasi yang baik, dimana maksud dari guru tidak dapat dipahami oleh siswa, sehingga siswa diam saja dan tidak merespon atau menanggapi tuturan tersebut.

\section{Saran}

Dalam interaksi belajar mengajar, khusunya di kelas akselerasi, perancangan proses pemelajaran oleh guru hendaknya berupa perancangan tindak komunikasi yang akan mengTemuankan pemahaman mendalam guna mencapai tujuan pemelajaran dan memperbaiki mutu pemelajaran di kelas. Dengan demikian perilaku guru terhadap siswa tampak sebagai upaya membangun komunikasi yang ideal dan komunikatif, menghindari suasana yang membosankan, tidak banyak berceramah, mengajukan pertanyaan yang menggali pengetahuan siswa secara aktif, serta menumbuhkan dan mengembangkan potensi siswa secara maksimal sesuai dengan karakteristik siswa akselerasi.

Masukan kepada kepala sekolah agar dapat memotivasi dan meminta komitmen para guru agar senantiasa merencanakan, mengembangkan, dan menerapkan aktivitas belajar mengajar dengan 
memanfaatkan potensi penggunaan bahasa guru dalam pembelajaran di kelas.

Bagi peneliti berikutnya, diharapkan dapat melakukan penelitian yang berhubungan dengan kajian lokusi, ilokusi, dan perlokusi yang fokus kajiannya terhadap bahasa yang digunakan siswa terhadap guru dan siswa terhadap siswa dalam wacana kelas.

\section{Daftar Pustaka}

Cummings, Louise. 2005. Pragmatics a Multidisciplinary Perspective. Edinburgh: Edinburg University.

Dardjowidjojo, Soenjono. 2005. Psikolinguistik. Jakarta: Yayasan Obor Indonesia.

Eka Chandra W, Dian. 2006. Kesantuan Dalam Komunikasi Multietnik Pendatang di Bengkulu. Disertasi Universitas Negeri Malang: Tidak Diterbitkan

Herry Widiastono, dkk. 1997. Profil Peserta Didik yang Memerlukan Perhatian Khusus dan yang Berkesulitan Belajar di Sekolah Lanjutan Tingkat Pertama. Jakarta: Depdikbud.

Ihsan, Diemroh. 2010. Pragmatik, Analisis Wacana, dan Bahasa Guru. Palembang: Universitas Sriwijaya.

Joni T Raka. 1985. Keterampilan Membuka dan Menutup Pelajaran. Jakarta: Departemen Pendidikan dan Kebudayaan.

Junaiyah, dkk. 2010. Keutuhan Wacana. Jakarta: Grasindo.
McCharty, M. 1991. Discourse Analysis for Language Teachers. Cambride: CUP.

Moleong, Lexy. 2007. Metodologi Penelitian Kualitatif. Bandung: Remaja Rosdakarya

Parera, Daniel J. 2004. Teori Semantik. Jakarta: Erlangga

Rahardi Kunjana. 2005. Pragmatik Kesantunan Imperatif Bahasa Indonesia. Malang: Dioma.

Rahardi, R. Kunjana. 2004. Berkenalan dengan Ilmu Bahasa Pragmatik. Malang: Dioma.

Rohmadi, Muhammad. 2004. Pragmatik Teori dan Analisis. Yogyakarta: Lingkar Media

Safnil. 2010. Pengantar Analisis Retorika Teks. Bengkulu: FKIP Unib .

Sardiman A.M. 2010. Interaksi dan Motivasi Belajar Mengajar. Jakarta: Rajawali Pers.

Sobur, Alex. 2001. Analisis Teks Media. Bandung: Remaja Rosdakarya.

Tarigan, H.G. 1986. Pengajaran Kosa Kata. Bandung: Angkasa.

Tarigan, Henry Guntur. 1990. Kedudukan dan fungsi bahas. Bandung: Angkasa

Trianto, Agus. 2012. Kajian Efektifitas Bahasa Guru PAUD di Bengkulu. Lembaga

Wijana, Dewa Putu. 1996. Dasar-dasar Pragmatik. Yogyakarta: Andi Offset 